\title{
Studying Bankruptcy of Companies Falling into the Liquidity Trap in Tehran Stock Exchange
}

\section{Estudiar la bancarrota de las empresas que caen en la trampa de liquidez en la Bolsa de Teherán}

\author{
Meysam Hajipoor \\ Islamic Azad University, Kish, Iran \\ ORCID: https://orcid.org/0000-0003-4492-7441 \\ Hamidreza Vakilifard* \\ Islamic Azad University, Tehran, Iran \\ ORCID: https://orcid.org/0000-0002-3608-1231 \\ Mehdi Mohammadi \\ Islamic Azad University, Zanjan, Iran \\ ORCID: https://orcid.org/0000-0002-1705-2873 \\ Godratolah Talebnia \\ Islamic Azad University, Tehran, Iran \\ ORCID: https://orcid.org/0000-0002-6448-1830
}

Received 02-12-20 Revised 02-25-20 Accepted 06-13-20 On line 06-29-20

*Correspondence

Email: h-vakilifard@srbiau.ac.ir
Cite as:

Hajipoor, M., Vakilifard, H., Mohammadi, M., \& Talebnia, G., Studying Bankruptcy of Companies Falling into the Liquidity Trap in Tehran Stock Exchange. Propósitos y Representaciones, 8 (SPE2), e668. Doi: http://dx.doi.org/10.20511/pyr2020.v8nSPE2.668 


\section{Summary}

Improper working capital policies may put companies in a situation where they may have difficulty securing their cash resources; in the financial sector, this is called a liquidity trap. The liquidity trap implies the inability of companies to provide cash resources due to inappropriate working capital policies. Theoretically speaking, companies falling into the liquidity trap have difficulty in fulfilling their obligations and paying off debts, due to applying proper liquidity policies; resulting from lack of cash flows or cash outflows, due to the internal or external factors, they are subject to financial limitations and ultimately bankruptcy. The purpose of this study is to investigate whether the companies listed in the Tehran Stock Exchange that have been fallen in the liquidity trap, eventually go bankrupt; using the data of 206 companies in the period of 20082017 and based on the liquidity trap prediction model of Vakili Fard et al., the financial limitation prediction models of Kaplan and Zingales, Witedo and modified Kaplan and Zingales, as well as modified Altman bankruptcy prediction models and genetic algorithm, we examined this hypothesis. Confirming the research hypothesis, it was concluded that companies with liquidity trap go bankrupt, unless they reform or change their working capital policies.

Keywords: Liquidity trap; Bankruptcy; Tehran; Stock Exchange.

\section{Resumen}

Las políticas inadecuadas de capital de trabajo pueden poner a las empresas en una situación en la que pueden tener dificultades para asegurar sus recursos en efectivo; En el sector financiero, esto se llama trampa de liquidez. La trampa de liquidez implica la incapacidad de las empresas para proporcionar recursos en efectivo debido a políticas inadecuadas de capital de trabajo. Teóricamente hablando, las empresas que caen en la trampa de liquidez tienen dificultades para cumplir con sus obligaciones y pagar deudas, debido a la aplicación de políticas de liquidez adecuadas; Como resultado de la falta de flujos de efectivo o salidas de efectivo, debido a factores internos o externos, están sujetos a limitaciones financieras y, en última instancia, a la quiebra. El propósito de este estudio es investigar si las compañías que cotizan en la Bolsa de Teherán que han caído en la trampa de liquidez eventualmente quiebran; utilizando los datos de 206 empresas en el período 2008-2017 y basado en el modelo de predicción de trampa de liquidez de Vakili Fard et al., los modelos de predicción de limitación financiera de Kaplan y Zingales, Witedo y Kaplan y Zingales modificados, así como Altman modificado Modelos de predicción de bancarrota y algoritmo genético, examinamos esta hipótesis. Confirmando la hipótesis de la investigación, se concluyó que las empresas con trampa de liquidez quiebran, a menos que reforman o cambian sus políticas de capital de trabajo.

Palabras clave: Trampa de liquidez; quiebra; Teherán; Bolsa de valores.

\section{Introduction}

Investors, owners, managers, creditors and state agencies are interested in assessing the financial status of companies, because a lot of costs are imposed on them in case of bankruptcy (Jabarzadeh Kangarlouie et al., 2009). In making financial decisions about an institution, a single scientific and factual index is required for each institution. Financial ratios are one of the tools for analyzing financial issues (Whitaker, 2019). Bankruptcy is the last stage of companies' economic life and occurs when the debts of a company exceed the value of the assets of the company (Altman, 1968); in other words, a company goes bankrupt when the total amount of debts exceeds the fair value of the total assets or the net value of the company's assets is negative (Lin, 2001). Bankruptcy is an event that affects all beneficiaries of the company (management, shareholders, employees, creditors, customers). On the other hand, the future growth of companies can also 
depend on management's sound decisions and correct understanding of the relationship between financial constraint, cash value and capital (Fazzari, 2018).

Bankruptcy prediction models are one of the techniques and tools for predicting the future status of companies; they estimate the probability of bankruptcy by combining a set of financial ratios. In analyzing ratios, the probability of bankruptcy is estimated by a group of financial ratios combined by the experts (Gitman, 1998).

Nowadays, different models are used to predict bankruptcy. By combining these ratios, the researchers have been able to develop multivariate models for predicting bankruptcy. Financial ratios provide some of the important facts about the operation and financial position of a profitmaking unit (Hossari, 2006).

Liquidity trap is an economic concept; it is a situation where, due to a very low interest rate, the investors are reluctant to buy bonds and prefer to store their capital in cash and in fact the demand for money is infinite (Akaike, 2015). In this situation, with the expectation that interest rates will rise, people will try to keep their capital in stagnant reserves to minimize the damage caused by rising interest rate (Sun \& Shenoy, 2007). In other words, it is expected to raise interest rate in the sense that money and financial resources become more expensive, in which case the buyers begin to hoard money in order not to be captured by future price increases (Poncet et al., 2010). In this research, the liquidity trap refers to a situation that is caused by incorrect working capital policies such as credit policies, short-term financing, etc. The company suffers from inability to timely provide cash resources in line with the operational activities (Zhang \& $\mathrm{Hu}$, 2014).

Given the above, the companies appear to be caught in the trap of liquidity as a result of inappropriate working capital policies. If this situation is continued, their financial limitations are increased and they eventually fall into bankruptcy (Ohlson, 2017). Therefore, in this research, we seek to investigate whether the companies that are in a liquidity trap situation or stage will eventually go bankrupt (Newton, 2016).

\section{Methods}

The research is conducted in four stages. The following describes each stage: Step One: Collecting Research Required Data: The statistical population of the research includes all the companies listed in the Tehran Stock Exchange from 2008 to 2017; the sample of the research includes all companies whose information related to the research variables was available and met the criteria for selecting companies, including the financial period ending March, non-interruption of trading for more than six months, etc. Relevant information accurately was computed from among more than 150,000 records and finally, a sample of 206 companies was selected.

\section{Research (Temporal, Spatial) Scope}

It is necessary for the research field that the research scope be fully explained. The scope of the present research is as follows:

Spatial scope: Since the main purpose of the present research is to investigate the bankruptcy of companies with liquidity trap in the Iranian capital market, therefore, the spatial scope of the present research is all companies listed in the Tehran Stock Exchange since 2008.

Temporal scope: The need to articulate the temporal scope of the research is more because the reader can eventually have a better understanding of the analyzes and inferences about the 
hypotheses, and indeed recognize the role of events, economic trends and socio-political conditions in research results. It is important to note that in social science researches, the national conditions have a major influence on the fate of their hypotheses and analyzes in an organizational setting (Khaki, 2005). Therefore, limiting the research timeframe makes interpretation of the results easy and improves their reliability.

\section{Results}

The time scope of this research is from 2008 to 2017. One of the reasons for choosing this time period is the possibility of extracting financial statements and accompanying notes during the desired time period; during the 9-year period, the researcher has been able to obtain the necessary information.

Step Two: Identifying the companies that are fallen into liquidity trap. For this purpose, information of sample companies is analyzed using the liquidity trap prediction model of Vakili et al. (2019) and the companies that are in liquidity trap condition are identified. This model is briefly described below:

$\mathrm{Y}_{1}=-4.1897+11.92 \mathrm{x}_{1 \mathrm{it}}+5.89 \mathrm{x}_{14 \mathrm{it}}+0.784 \mathrm{x}_{25 \mathrm{it}}+2.846 \mathrm{x}_{3 \mathrm{it}}-3.297 \mathrm{x}_{5 \mathrm{it}}$

$\mathrm{Y}_{2}=-0.627+28.60584 \mathrm{x}_{18 \mathrm{it}}+28.60583 \mathrm{x}_{20 \mathrm{it}}+28.60590 \mathrm{x}_{31 \mathrm{it}}$

$Y_{1}$ : Liquidity Trap Forecasting Model for Variables and Currency Ratios

$\mathrm{Y}_{2}$ : Liquidity Trap Forecasting Model for Variables and temporal Ratios

(Table 1) shows the ratios in the above patterns.

Table 1.

Liquidity Trap Model Variables

\begin{tabular}{ll}
\hline Currency ratios & Temporal ratios \\
\hline $\begin{array}{l}\mathrm{X}_{1}=\text { Profit before interest and tax on total } \\
\text { assets }\end{array}$ & $\begin{array}{l}\mathrm{X}_{18}=\text { Ratio of financial claims collection } \\
\text { period }\end{array}$ \\
\hline $\mathrm{X}_{3}=$ Distributable net profit on Total Assets & $\mathrm{X}_{20}=$ Inventory preservation Ratio \\
\hline $\mathrm{X}_{5}=$ Current Assets to Total Assets & $\mathrm{X}_{31}=$ Operation Period Ratio \\
\hline $\mathrm{X}_{14}=$ Sales to Total Assets & \\
\hline $\mathrm{X}_{25}=$ Accumulated Profit and Loss on Total & \\
Assets & \\
\hline
\end{tabular}

A company will be considered as fallen into liquidity trap that is caught in both the Currency pattern and the liquidity trap temporal pattern.

Step Three: Examining the status of the companies identified in the liquidity trap in subsequent years. That either these companies become financially constrained and eventually bankrupt due to the type of their working capital policies or they continue to survive. In order to achieve the objectives of the research and testing the hypotheses, the financial limitation models of Witdo, Kaplan and Zingales and adjusted Kaplan and Zingales, as well as the (Altman, 1968) bankruptcy models and the genetic algorithm were selected, which are briefly mentioned below in (Table 2).

Kaplan \& Zingles Financial Limitation Model (KZ): it is the financial constraint criterion developed by Kaplan and Zingales in 1998 and can be calculated as follows. 
$\mathrm{KZ}=\quad-1.002 *\left[\frac{\text { Cash flow }_{\mathrm{i}, \mathrm{t}}}{\text { Total Assets }_{\mathrm{i}, \mathrm{t}}}\right]+0.283 * \frac{\mathrm{M}_{\mathrm{i}, \mathrm{t}}}{\mathrm{B}_{\mathrm{i}, \mathrm{t}}}+3.139 *\left[\frac{\text { Debt }_{\mathrm{i}, \mathrm{t}}}{\text { Total Capital }_{\mathrm{i}, \mathrm{t}}}\right]-39.368 *$
$\left[\frac{\text { Divi.t }_{\mathrm{i} . \mathrm{t}}}{\text { Total Assest }_{\mathrm{i}, \mathrm{t}}}\right]-1.315\left[\frac{\text { Cash holding }_{\mathrm{i}, \mathrm{t}}}{\text { Total Assets }_{\mathrm{i}, \mathrm{t}}}\right]$

Table 2.

Kaplan and Zingales financial limitation model variables

Total Assets ${ }_{i, t}=$ the total assets of the company

Debt ${ }_{i, t}=$ the total debt of the company

Total Capital ${ }_{i, t}=$ the total net book value of the company that represents the net asset of the company

Div $_{i, t}=$ the dividend of the company

Cash holding $\mathrm{i}, \mathrm{t}=\left(\operatorname{cash}_{\mathrm{i}, \mathrm{t}}+\right.$ short term investment $\left._{\mathrm{i}, \mathrm{t}}\right)$

$M_{i, t}=$ the market value of the company

$B_{i, t}=$ the book value of the company

Cash flow $i, t=$ net cash flow of a company divided by the total assets of the company

Kaplan and Zingales Modified financial limitation model: Rai and Hesarzadeh in 2009 presented the Kaplan and Zingales model with respect to Iran Coordinates (KzIR) as follows:

$\mathrm{Kz}_{\mathrm{IR}}=\quad 17.33-37.486 *\left[\frac{\text { Cash holding }_{\mathrm{i}, \mathrm{t}}}{\text { Total Assets }_{\mathrm{i}, \mathrm{t}}}\right]-15.21 *\left[\frac{\text { Divi.t }_{\mathrm{i}}}{\text { Total Assest }_{\mathrm{i}, \mathrm{t}}}\right]+3.39 *\left[\frac{\text { Debt }_{\mathrm{i}, \mathrm{t}}}{\text { Total Assest }_{\mathrm{i}, \mathrm{t}}}\right]-$ $1.402 * \frac{\mathrm{M}_{\mathrm{i}, \mathrm{t}}}{\mathrm{B}_{\mathrm{i}, \mathrm{t}}}$

Whitedo Financial Limitation Model (WW): it is the financial limitation model, presented by Whitedo in 2006, and can be calculated as follows in (Table 3).

$\mathrm{WW}=\quad-0.091 \mathrm{Cf}_{\mathrm{i}, \mathrm{t}}-0.062$ Div Dummy $+0.02 \mathrm{TLTD}_{\mathrm{i}, \mathrm{t}}-0.044 \mathrm{LNTA}_{\mathrm{i}, \mathrm{t}}+1.02 \mathrm{ISG}_{\mathrm{i}, \mathrm{t}}-$ $0.035 G_{i, t}$

Table 3.

Whitedo model variables

$\mathrm{CF}_{\mathrm{i}, \mathrm{t}}=\left[\frac{\text { Cash flow }_{\mathrm{i}, \mathrm{t}}}{\text { Total Assets }_{i, \mathrm{t}}}\right]=$ Operating cash flow on the total assets

Div Dummy $=$ a virtual variable and for companies that have had dividend over the period will be equal to 1 and otherwise equal to 0

$\mathrm{TLT}_{\mathrm{i}, \mathrm{t}}=\left[\frac{\text { Total long Term Debt }_{\mathrm{i}, \mathrm{t}}}{\text { Total Assets }_{\mathrm{i}, \mathrm{t}}}\right]=$ Total long-term debts on the total assets

LNTA $_{i, t}=\operatorname{Ln}\left(\right.$ Total Assets $\left._{i, t}\right)=$ The natural logarithm of all assets.

$\mathrm{TSG}_{\mathrm{i}, \mathrm{t}}=$ The growth of industrial sales in which the company is located

$\mathrm{SG}_{\mathrm{i}, \mathrm{t}}=\left[\frac{\text { Sale }_{\mathrm{i} . \mathrm{t}}-\text { Sale }_{\mathrm{i} . \mathrm{t}-1}}{\text { Sale }_{\mathrm{i} . \mathrm{t}-1}}\right]=$ company's sale 


\section{Discussion}

Altman Bankruptcy Model: The most famous model of predicting financial distress and bankruptcy was presented in 1968 by Altman using Multiple Diagnostic Analysis. (Altman, 1968) presented two other models with the pathology of the models presented. (Jones, 2015) showed that because the Altman model was designed in a different economic environment and its unmodified implementation in Iranian environment was of high error, so by re-executing the Altman model, the coefficients of this model were adjusted according to the Iranian economic environment:

$\mathrm{T}=0 / 291 \mathrm{X}_{1}+2 / 485 \mathrm{X}_{2}-0 / 301 \mathrm{X}_{3}-0 / 079 \mathrm{X}_{4}-0 / 05 \mathrm{X}_{5}$

$\mathrm{X} 1=$ Total working capital / working asset

$\mathrm{X} 2$ = Total Accumulated Assets / Profit

$\mathrm{X} 3$ = Total before-tax and before-interest Assets / Income

$\mathrm{X} 4=$ Debt book value / equity market value

X5 $=$ Total Assets $/$ Total Sales

Therefore, the Altman model modified by (Jones, 2015) was used in this research.

Genetic Algorithm Bankruptcy Predictive Model: In this research, Genetic Algorithm Bankruptcy Prediction Model was used, which is based on the Iranian capital market information and was obtained by (Dun \& Bradstreet, 2011). By applying genetic algorithm, 5 variables were selected as final variables:

1. The ratio of current assets / current debts $\left(\mathrm{x}_{2}\right)$.

2. The ratio of Cash / current Debt $\left(\mathrm{x}_{3}\right)$.

3. The ratio of Current Asset - Goods Inventory / Current Debts $\left(\mathrm{x}_{5}\right)$

4. The ratio of Net Sales / Total Assets $\left(\mathrm{x}_{14}\right)$

5- The ratio of Net Profit / Total Assets $\left(\mathrm{x}_{18}\right)$

If $\mathrm{X} 2<1.28, \mathrm{X} 3<0.847, \mathrm{X} 5<0.697, \mathrm{X} 14<0.685, \mathrm{X} 18<0.17$, the company is bankrupt and otherwise the company will not be bankrupt.

Step Four: Testing the Research Hypothesis and Conclusion

Based on the results of the implementation of the liquidity trap model, the financial limitation models and the bankruptcy models that were calculated for the selected companies in different years, the research hypothesis was tested as follows:

Research hypothesis: Companies with liquidity trap go bankrupt.

(Table 4) shows the results of the implementation of the models of liquidity trap forecasting, financial limitation and bankruptcy for sample companies.

\section{Table 4.}

Simultaneous examination of three financial limitation patterns for year 2015 and bankruptcy for year 2016 for companies falling into liquidity trap in year 2014

\begin{tabular}{|c|c|c|c|c|}
\hline $\begin{array}{l}\text { Status of liquidity } \\
\text { trap in } 2014\end{array}$ & $\begin{array}{l}\text { Status of } \\
2015\end{array}$ & cial limitation in & Status of ba & $y$ in 2016 \\
\hline Fallen into liquidity & with & 29 & Bankrupted & 25 \\
\hline $\begin{array}{l}\operatorname{trap} \\
55\end{array}$ & $\begin{array}{l}\text { financial } \\
\text { limitation }\end{array}$ & $52.7 \%$ & & $45.5 \%$ \\
\hline $26.7 \%$ & without & 26 & Healthy & 30 \\
\hline & $\begin{array}{l}\text { financial } \\
\text { limitation }\end{array}$ & $47.2 \%$ & & $54.5 \%$ \\
\hline Healthy & & 79 & Bankrupted & 51 \\
\hline
\end{tabular}




\begin{tabular}{|c|c|c|c|c|}
\hline \multirow[t]{3}{*}{$\begin{array}{l}151 \\
73.3 \%\end{array}$} & $\begin{array}{l}\text { with } \\
\text { financial } \\
\text { limitation }\end{array}$ & $52.3 \%$ & & $33.8 \%$ \\
\hline & without & 72 & \multirow{2}{*}{ Healthy } & 100 \\
\hline & $\begin{array}{l}\text { financial } \\
\text { limitation }\end{array}$ & $47.7 \%$ & & $66.2 \%$ \\
\hline
\end{tabular}

\section{Conclusion}

Among the companies with liquidity trap in 2015 , whose number was 55 , about $52.7 \%$ of them in the following year i.e. 2015 were suffered from financial limitation and about $45.5 \%$ of them in next two years i.e. 2016 went bankrupt. So it can be concluded that companies fallen into liquidity trap go bankrupt if they do not reform or change their working capital policies.

\section{References}

Jabarzadeh Kangarlouie S. \& Khodayar Yeganeh S. \& Pourreza Sultan Ahmadi A. (2009), "Investigating the Relationship between Earning Smoothing and Companies' Helplessness in Tehran Stock Exchange", Quarterly Journal of Financial Accounting, 1(2): $60-80$.

Whitaker R. (2019). "The Early Stage of Financial Distress". Journal of Economics and Finance, 23(2): 123-133.

Altman E. (1968), Financial Ratios, Disarmament Analysis and the Prediction of Corporate Bankruptcy, The Journal of Finance, 23(5): 589-609.

Lin L. (2001), The Identification of Corporate Distress, Review of Quantitative Finance and Accounting, 8(6): 29-45.

Fazzari S. (2018), "Investment -Cash Flow Sensitivities are Useful", Quarterly Journal of Economic, 115 (2): 695-705.

Gitman L. (1998), Principle of Managerial Finance. Working paper. New York: Harper Collins College, 18(3): 130-145.

Hossari G. (2006), A Dynamic Ratio - Based Model for Signaling Corporate Collapse, Jamar, 4(5): 10-32.

Akaike H. (2015), "A new look at the statistical model identification", IEEE Transactions on Automatic Control, 19(6): 716-723.

Sun L. \& Shenoy P. (2007), Using Bayesian Networks for Bankruptcy Prediction, European Journal of Operational Research, 18(2): 738-753.

Poncet S. \& Walter S. \& Hylke V. (2010), Financial constraints in China: Firmlevel evidence, China Economic Review, 15(6): 411-422.

Zhang G. \& Hu M. (2014), Artificial Neural Networks in Bankruptcy Prediction, European Journal of Operational Research, 6(2): 16-32.

Ohlson J. (2017), Financial Ratios and the Probabilistic Prediction of Bankruptcy, Journal of Accounting Research, 18(5): 109-131.

Newton G. (2016), Bankruptcy Insolvency Accounting Practice and Procedure, Financial Accounting Researches, 11(4): 21-41.

Jones F. (2015), Current Techniques in Bankruptcy Prediction, Journal of Accounting Literature, 7(3): 121-130.

Dun S. \& Bradstreet F. (2011), Bankruptcy Insolvency Accounting Practice and Procedure. Wiley, 17(5): 21-41. 